\title{
E-CoMmerce Mobile MARKETINg MODEL Resolving Users ACCEPTANCE Criteria
}

\author{
Veronica S. Moertini ${ }^{1}$ and Criswanto D. Nugroho ${ }^{2}$ \\ ${ }^{1,2}$ Informatics Department \\ Parahyangan Catholic University, Bandung, Indonesia \\ ${ }^{1}$ moertini@unpar.ac.id, ${ }^{2}$ arthur2112@gmail.com
}

\begin{abstract}
The growth of e-commerce and mobile services has been creating business opportunities. Among these, mobile marketing is predicted to be a new trend of marketing. As mobile devices are personal tools such that the services ought to be unique, in the last few years, researches have been conducted studies related to the user acceptance of mobile services and produced results. This research aims to develop a model of mobile e-commerce mobile marketing system, in the form of computer-based information system (CBIS) that addresses the recommendations or criteria formulated by researchers. In this paper, the criteria formulated by researches are presented then each of the criteria is resolved and translated into mobile services. A model of CBIS, which is an integration of a website and a mobile application, is designed to materialize the mobile services. The model is presented in the form of business model, system procedures, network topology, software model of the website and mobile application, and database models.
\end{abstract}

\section{KEYWORDS}

Mobile Marketing System, E-Commerce Marketing, Mobile Services Criteria

\section{INTRODUCTION}

It is known that in many areas of the world, the Internet and mobile devices users have grown tremendously in the last several years. For example, in the case of Indonesia, the Internet users of 2011 was 55 million people which was expanded 27 folds compared to the 2 million users in 2000 [21]. On the other hand, the number of mobile devices (such as smartphones and tablet computers) used in 2012 is 268 million and is predicted to be 650 million in 2015 [23]. Interestingly, $48 \%$ of the Internet users in Indonesia utilize mobile devices to access it [25].

In line with this trend, in the last decade e-commerce has also been growing exponentially [9] and so has mobile services, which has been creating a large spectrum of business opportunities [14]. Among the opportunities, mobile marketing is predicted to be a new trend of marketing on a world-wide basis [1]. Hence, it can also be predicted that e-commerce mobile marketing will also be growing significantly.

As mobile devices are personal tools that are carried by the owners wherever they go, mobile services are different from non-mobile services in that mobile services should be designed based on personalization, ubiquity and location specificity [14]. Mobile devices are also ideal platforms for integrating messages, developing relationship and direct marketing [1]. 
International Journal of Managing Information Technology (IJMIT) Vol.4, No.4, November 2012

Researchers have been aware of the trends, the opportunities and the uniqueness of mobile services. In the last few years, several studies related to user acceptance of mobile services have been conducted. As the results of these studies, researchers have formulated guidance, recommendations or some kind of criteria (see Sub-section 4.2 for more discussion) that can be adopted by organizations, enterprises or mobile services developers such that the services designed will be widely accepted by users. This research aims to develop a model of mobile ecommerce marketing system, in the form of computer-based information system (CBIS) model that addresses the recommendations or criteria formulated by researchers.

The contribution of this paper can be described as follows. Although several studies have recently formulated recommendations, the authors have not found any research result that adopts these recommendations in designing an integrated computer-based information system (CBIS) used for e-commerce mobile marketing systems. Therefore, this research intends to contribute in this area.

As the system being developed is a CBIS that integrates an e-commerce website and a mobile application, the research methods adopted are the combination of CBIS, e-commerce website and mobile applications development. However, this research focuses on requirement and analysis stages only (see Section 2.3 for the discussion of the all development stages).

The article is arranged as follows: The next section presents the related literatures; Section 3 presents the proposed CBIS development methods; Section 4 discusses the business objectives, mobile services criteria and proposed services solutions; Section 5 describes the proposed business model; Section 6 presents the proposed mobile marketing system (CBIS) model consisting of network infrastructure, people and system procedures, software and database model; Section 7 depicts the model evaluation; Section 8 provides the conclusion and further work where we suggest that the proposed mobile marketing system can be implemented as a standalone system as well as a sub-system of an integrated e-commerce system.

\section{RELATED LITERATURES}

\subsection{Online Communication Techniques in the Purchasing Process}

Purchasing process of products and services generally consists of a few stages, which are awareness (recognizing needs), products or services searching, evaluations of alternatives, purchasing and post-purchasing. In online communications, there are a few techniques that can be adopted by enterprises to support their customers or market their products as depicted on Chart 1.

Chart 1. Online communication techniques in the purchasing process [9]

\begin{tabular}{|l|l|l|l|l|l|}
\hline $\begin{array}{l}\text { Online } \\
\text { communication } \\
\text { techniques }\end{array}$ & Awareness & Searching & $\begin{array}{l}\text { Evaluating } \\
\text { Alternatives }\end{array}$ & Purchasing & $\begin{array}{l}\text { Post- } \\
\text { Purchasing }\end{array}$ \\
\hline $\begin{array}{l}\text { Description of } \\
\text { the technique }\end{array}$ & $\begin{array}{l}\text { targeted } \\
\text { banner ads, } \\
\text { interstitials, } \\
\text { targeted } \\
\text { event } \\
\text { promotions }\end{array}$ & $\begin{array}{l}\text { search } \\
\text { engines, } \\
\text { online } \\
\text { catalogs, } \\
\text { website } \\
\text { visits, } \\
\text { targeted } \\
\text { email }\end{array}$ & $\begin{array}{l}\text { search engines, } \\
\text { online } \\
\text { catalogs, } \\
\text { website visits, } \\
\text { product } \\
\text { reviews, user } \\
\text { evaluations }\end{array}$ & $\begin{array}{l}\text { lotteries, } \\
\text { discounts, } \\
\text { targeted } \\
\text { email }\end{array}$ & $\begin{array}{l}\text { enline } \\
\text { comastomer, } \\
\text { email, } \\
\text { online } \\
\text { updated }\end{array}$ \\
\hline
\end{tabular}


International Journal of Managing Information Technology (IJMIT) Vol.4, No.4, November 2012

\subsection{Eight Key Elements of a Business Model}

In attempt to develop a successful business model, one has to ensure that the following eight key elements are addressed [9]: (1) Value proposition: Define how a company's product or service fulfils the needs of customers; (2) Revenue model: Describe how the company will earn revenue; (3) Market opportunity: Define the market space/segment and overall potential opportunity available; (4) Competitive environment: Describe other companies operating in the same market space/segment; (5) Competitive advantage: Design the superior products/services compared to the ones provided by competitors; (6) Market Strategy: Design the plan to enter a new market and attract new customers; (7) Organizational development: Plan how the company will need to organize the required tasks; (8) Management team: Organize employees conducting the tasks.

\subsection{CBIS, e-Commerce Website and Mobile Application Development}

There are several approaches applied to develop Computer Based Information Systems (CBIS), such as water fall and rapid and evolutionary development. Disregarding the selected approach, the stages will include requirement, analysis, design, implementation and test. Some excerpts of the activities in each stage are shown in Chart 2 [2].

Chart 2. The activities in each stage of CBIS development.

\begin{tabular}{|l|l|}
\hline \multicolumn{1}{|c|}{ Stage } & \multicolumn{1}{|c|}{ Activities } \\
\hline (a) Requirement & $\begin{array}{l}\text { Detailed fact-finding will be performed by studying the existing or } \\
\text { legacy system with the aims of capturing the data used, procedures, } \\
\text { who are involved, the roles of the unit organization or individual staff } \\
\text { involved, the problems encountered while doing their tasks, reports } \\
\text { needed and so on, then, functional as well as non-functional } \\
\text { requirements of the new CBIS are defined. }\end{array}$ \\
\hline $\begin{array}{l}\text { (b) System } \\
\text { Analysis }\end{array}$ & $\begin{array}{l}\text { Based on the result of the previous stage, this stage proposes the } \\
\text { architecture of the whole system, hardware and network infrastructure } \\
\text { needed by the new CBIS, designs the new procedures, models the } \\
\text { software or application and conceptually designs the database. }\end{array}$ \\
\hline $\begin{array}{l}\text { (c) System Design } \\
\text { and Testing }\end{array}$ & $\begin{array}{l}\text { Detailed design of the software and database are constructed. } \\
\text { installed, tested and run while the design of the software and database } \\
\text { are coded and tested. }\end{array}$ \\
\hline
\end{tabular}

Similar to CBIS development, [9] suggests five major steps in developing e-commerce website, which are systems analysis/planning, systems design, building the system, testing and implementation. As this research uses the analysis and some part of system design stages only, brief discussion of these two stages are provided as follows. In the stage of system analysis, the activities that must be performed are defining: (a) Business objectives containing list of the website capabilities; (b) System functionalities containing list of information system capabilities needed to achieve business objectives; (c) Information requirements describing information elements that system must produce in order to achieve business objectives. In the stage of systems design, the hardware and software platforms are designed and the description of main components of the system and their relationship to one another are constructed. 
International Journal of Managing Information Technology (IJMIT) Vol.4, No.4, November 2012

In developing mobile applications, [7] suggests that the developer focus on "what is right" for the users including their context, goals, and needs. Therefore, the stages of the application designs are: Defining the users' context, uncover the users' goals, with goals understood, figuring out the tasks the users want to perform; also looking for ways to filter content by context, such as location, media, and model.

Cloud computing offers many advantages and has been gaining popularity. Generally, there are three kinds of cloud computing service models, namely Software-As-a-Service (SaaS), PlatformAs-a-Service (PaaS) and Infrastructure-As-a-Service (IaaS) ([15] and [12]). PaaS is a variation of SaaS whereby the development environment is offered as a service. The developers use the building blocks (e.g., predefined blocks of code) of the vendor's development environment to create their own applications. One of the well-known vendors providing these services is Google. A service provided by Google, namely Android Cloud to Device Messaging (C2DM), allows third-party application servers to send lightweight messages to mobile Android applications [22]. This service is not designed for sending a lot of content via the messages. Rather, it should be used to tell the application that there is new data on the server, so that the client application can fetch it. In the context of mobile application development, this service can be adopted to provide push notification services.

\section{Proposed System DeVelopment Methods}

This research presents the research results in the requirement and analysis stages of CBIS development. The marketing system that will be developed uses a CBIS that integrates an ecommerce website and a mobile application. Hence, the development method that we propose is the combination of CBIS, e-commerce website and mobile applications development with stages of requirement, systems analysis, systems design, building the system, testing and implementation. Here, we enhance the requirement stage that is excerpted as follows:

(a) Based on the problems found and business opportunities, business objectives are defined.

(b) As a part of the mobile marketing system being developed is a mobile application, the strategy suggested by Fling in [6] is adopted. "What is right" for mobile users (see Subsection 2.3) will be searched by studying literature presenting research results associated with the mobile services that are accepted by users. The results of the study will be grouped into several criteria that will be resolved in the next stages of the development.

(c) Resolving the criteria that have been formulated into services of the website and mobile application to achieve business objectives.

(d) Formulating the appropriate business model that can provide the services defined.

Once the requirement stage has been performed, activities in the system analysis stage of a CBIS development (see Sub-section 2.3) are conducted.

\section{Business Objectives, Mobile Marketing Services Criteria AND SERVICES SOLUTIONS}

\subsection{Business Objectives}

The main business objective of the proposed mobile marketing system is to provide services for merchants to market their products to customers who own mobile devices with functionalities to access the Internet. 
International Journal of Managing Information Technology (IJMIT) Vol.4, No.4, November 2012

In order to support sales by mobile device, the purchasing stages (see Sub-section 2.1) that will be supported by the system are: (a) Awareness: targeted ads and promotions/coupons/deals; (b) Searching products: search engines and online catalogs; (b) Evaluating products: search engines, online catalogs, product reviews and users/peers evaluations; (c) Purchasing products: electronic promotions/coupons/deals; (d) Post-purchasing products: online product information update. In order to enable mobile customers to utilize the system services, the system must also provide services for merchants, which are as follows: (a) Registering as members and manage profile; (b) Managing product catalogs; (c) Managing ads, promotions/coupons/deals and the targeted market segment for the ads and deals.

\subsection{Mobile Services Acceptance Criteria}

In attempting to search "what is right" for mobile users, several literatures presenting research results of mobile users' acceptance towards mobile services have been studied. Chart 3 summarizes the main suggestions of researchers for enhancing user's acceptance.

Chart 3. The summary of research results of mobile marketing service criteria

\begin{tabular}{|c|c|c|}
\hline Criteria & Reference & Researchers Suggestions \\
\hline $\begin{array}{l}\text { Cr-1. Customer } \\
\text { permission }\end{array}$ & [1] & $\begin{array}{l}\text { Companies should take permission from consumers and } \\
\text { give them incentive to participate in mobile ads. }\end{array}$ \\
\hline $\begin{array}{l}\mathrm{Cr}-2 . \text { Ease of } \\
\text { use }\end{array}$ & $\begin{array}{l}{[14] ;[13]} \\
{[10] ;[18]}\end{array}$ & $\begin{array}{l}\text { Users are more likely to accept mobile services, if they } \\
\text { find that these services are easy to use. }\end{array}$ \\
\hline $\begin{array}{l}\text { Cr-3. } \\
\text { Usefulness }\end{array}$ & $\begin{array}{l}{[14] ;[13]} \\
{[20]}\end{array}$ & $\begin{array}{l}\text { Usefulness is essential for mobile viral content and the } \\
\text { behavioral intention of adopting mobile services is } \\
\text { affected by perceived usefulness. }\end{array}$ \\
\hline $\begin{array}{l}\text { Cr-4. Relevant } \\
\text { content, } \\
\text { personalization }\end{array}$ & {$[1] ;[11]$} & $\begin{array}{l}\text { Consumers are willing to accept mobile ads provided they } \\
\text { are given relevant content. The amount of personalized } \\
\text { services also has direct on user payoff. }\end{array}$ \\
\hline $\begin{array}{l}\text { Cr-5. } \\
\text { Compelling } \\
\text { content }\end{array}$ & $\begin{array}{l}{[1] ;[7] ;} \\
{[14] ;[13]}\end{array}$ & $\begin{array}{l}\text { Entertainment, amusement and enjoyment are important } \\
\text { variables to improving mobile advertising attitudes. } \\
\text { Compelling content will also stimulate viral activity. }\end{array}$ \\
\hline $\begin{array}{l}\text { Cr-6. } \\
\text { Timely/up-to- } \\
\text { date content }\end{array}$ & {$[13]$} & Mobile viral content should be delivered on time. \\
\hline $\begin{array}{l}\text { Cr-7. Services } \\
\text { compatible } \\
\text { with customers } \\
\text { life styles or } \\
\text { habits }\end{array}$ & [10] & $\begin{array}{l}\text { The compatibility of the technology with customers' life } \\
\text { styles or habits is a very important motivator for using } \\
\text { mobile internet. }\end{array}$ \\
\hline $\begin{array}{l}\text { Cr-8. Location- } \\
\text { aware } \\
\text { advertising }\end{array}$ & {$[3]$} & $\begin{array}{l}\text { Location-aware advertising text messages are preferred } \\
\text { over those that are not location aware. }\end{array}$ \\
\hline $\begin{array}{l}\text { Cr-9. } \\
\text { Increasing } \\
\text { gains in } \\
\text { shopping } \\
\text { performance } \\
\end{array}$ & {$[18]$} & $\begin{array}{l}\text { Consumers will adopt mobile shopping services if they } \\
\text { believe that using the services will help them to increase } \\
\text { gains in shopping performance (e.g., saving shopping time } \\
\text { and obtaining promotion information). }\end{array}$ \\
\hline $\begin{array}{l}\mathrm{Cr}-10 \text {. } \\
\text { Incentive, } \\
\text { rewards }\end{array}$ & $\begin{array}{l}{[1] ;[3] ;} \\
{[7] ;[13]}\end{array}$ & $\begin{array}{l}\text { Incentives, rewards and value propositions are important } \\
\text { variables to improving mobile advertising such that these } \\
\text { can elicit more positive reactions than those without such } \\
\text { rewards. }\end{array}$ \\
\hline
\end{tabular}


International Journal of Managing Information Technology (IJMIT) Vol.4, No.4, November 2012

\begin{tabular}{|l|l|l|}
\hline \multicolumn{1}{|c|}{ Criteria } & Reference & \multicolumn{1}{c|}{ Researchers Suggestions } \\
\hline $\begin{array}{l}\text { Cr-11. } \\
\text { Enhancing } \\
\text { customers } \\
\text { image }\end{array}$ & {$[14] ;[13]$} & $\begin{array}{l}\text { Mobile users who could communicate with peers in a } \\
\text { funny way or who are well-informed helpers can be } \\
\text { viewed as experts in their social network. }\end{array}$ \\
\hline $\begin{array}{l}\text { Cr-12. } \\
\text { Interpersonal } \\
\text { and external } \\
\text { influence, } \\
\text { social network }\end{array}$ & {$[14] ;[20] ;$} & $\begin{array}{l}\text { Interpersonal and external influence has a positive } \\
\text { influence towards adopting mobile services. Consumers } \\
\text { will be influenced by word-of-mouth and others' opinions. }\end{array}$ \\
\hline $\begin{array}{l}\text { Cr-13. Security } \\
\text { and privacy } \\
\text { protection }\end{array}$ & {$[14] ;[7] ;$} & $\begin{array}{l}\text { Security and privacy protection have a positive influence } \\
\text { on the adoption of mobile services. }\end{array}$ \\
\hline
\end{tabular}

\subsection{Resolving Mobile Services Acceptance Criteria}

Younes and Megdadi in [19] conclude that mobile advertising, either in a push or pull mode, is a key component of mobile marketing communication, where the push model will dominate mobile advertising (since it saves consumers' time and money). It also states that sales promotion in the form of mobile coupons play a vital role and has some advantages. On the other hand, [3] and [17] suggest that mobile applications must determine the user's location before offering services and then continually track the location to adapt services and information accordingly.

We design mobile marketing services resolving the users' acceptance criteria (presented in Chart 3 ) that are based on the push model and offering services that are aware of the users' location. The services are grouped into mobile (for customers) and website (for merchants) and depicted in Chart 4.

Chart 4. System services resolving mobile advertising acceptance criteria

\begin{tabular}{|l|l|}
\hline \multicolumn{1}{|c|}{ Criteria } & \multicolumn{1}{c|}{ System Services as the Solutions } \\
\hline $\begin{array}{l}\text { Customer } \\
\text { permission }\end{array}$ & $\begin{array}{l}\text { Mobile services: MSr-1. Services for sign up/registration: Customers } \\
\text { will receive products information and advertisings after they voluntarily } \\
\text { register as web-ads members. }\end{array}$ \\
\hline Ease of use & $\begin{array}{l}\text { Mobile services: MSr-2. Simple, self-explanatory, easy and consistent } \\
\text { navigation user interfaces. }\end{array}$ \\
\hline $\begin{array}{l}\text { Usefulness, } \\
\text { relevant } \\
\text { content, } \\
\text { compelling } \\
\text { content } \\
\text { personalized } \\
\text { content }\end{array}$ & $\begin{array}{l}\text { Mobile services: MSr-3. Delivering information of products under the } \\
\text { categories selected by customer only; MSr-4. Filtering ads and } \\
\text { deals/coupons based on customer profile. }\end{array}$ \\
\hline $\begin{array}{l}\text { Website services: WSr-1. Manage product catalogs; WSr-2. Manage ads, } \\
\text { deals and market segmentation variables used in computing the targeted } \\
\text { market segment for the corresponding ads and deals; } \\
\text { content }\end{array}$ & $\begin{array}{l}\text { Mobile services: MSr-5. Providing deals/coupons that can be redeemed } \\
\text { when customers purchase goods in the merchant stores; MSr-6. } \\
\text { Providing easily accessed product catalog, ads, deals and messages with } \\
\text { interesting interfaces. } \\
\text { Website services: WSr-2. }\end{array}$ \\
\hline $\begin{array}{l}\text { Timely and up- } \\
\text { to-date content }\end{array}$ & $\begin{array}{l}\text { Mobile services: MSr-7. Sending products update, ads and deals in real } \\
\text { time basis (whenever merchants update any of these, registered }\end{array}$ \\
\hline
\end{tabular}


International Journal of Managing Information Technology (IJMIT) Vol.4, No.4, November 2012

\begin{tabular}{|c|c|}
\hline Criteria & System Services as the Solutions \\
\hline & $\begin{array}{l}\text { customers will be promptly notified with push notification via cloud } \\
\text { services). } \\
\text { Website services: WSr-3. Update/add product categories, catalogs, ads, } \\
\text { deals (customers will be updated promptly each time new data is } \\
\text { posted/updated). }\end{array}$ \\
\hline $\begin{array}{l}\text { Location-aware } \\
\text { advertising }\end{array}$ & $\begin{array}{l}\text { Mobile services: MSr- } 8 \text {. Customers will receive information coming } \\
\text { from the nearby merchants only; MSr-9. Services for showing the } \\
\text { location or map of each merchant. } \\
\text { Website services: WSr-4. Manage stores location. }\end{array}$ \\
\hline $\begin{array}{l}\text { Increasing gains } \\
\text { in shopping } \\
\text { performance }\end{array}$ & $\begin{array}{l}\text { Mobile services: MSr-5; MSr-10. Sending ads and deals matching with } \\
\text { customers personality from the nearby merchants to promote efficiency } \\
\text { in selecting and purchasing products; MSr-11. Services for comparing } \\
\text { products; MSr-12. Services to mark favorite products and receive } \\
\text { notifications if the products are on sale; MSr-13. Services for asking } \\
\text { opinions from friends regarding the products of interest. } \\
\text { Website services: WSr-2. }\end{array}$ \\
\hline $\begin{array}{l}\text { Incentive, } \\
\text { rewards }\end{array}$ & $\begin{array}{l}\text { Mobile services: MSr-5. } \\
\text { Website services: WSr- } 2 \text {. }\end{array}$ \\
\hline $\begin{array}{l}\text { Enhancing } \\
\text { customers } \\
\text { image }\end{array}$ & $\begin{array}{l}\text { Mobile services: MSr-6; MSr-7; MSr-14. Services for sharing } \\
\text { information of products, advertising and promotions/deals to peers; }\end{array}$ \\
\hline $\begin{array}{l}\text { Interpersonal } \\
\text { and external } \\
\text { influence, social } \\
\text { network }\end{array}$ & Mobile services: MSr-13; MSr-14; \\
\hline $\begin{array}{l}\text { Security and } \\
\text { privacy } \\
\text { protection }\end{array}$ & $\begin{array}{l}\text { Mobile services: MSr-15. Services for filling customer profile that will } \\
\text { be stored in the local mobile database and are not accessible by other } \\
\text { parties (the profile will be used to filter the incoming ads and deals); } \\
\text { MSr-16. Services for storing favorite products and deals taken in the } \\
\text { local mobile database such that others will not know. }\end{array}$ \\
\hline
\end{tabular}

The data that will be required, accessed or managed by the services are:

(a) Website services: Data of products including product categories, product catalog, description and pictures; merchants including profile and membership; customer/shopper profile; market segment variables, ads description; deals description including stocks; messages/notifications/comments.

(b) Mobile services: Data of products including selected product categories, product catalog, description and pictures; user profile; shopper peers; market segment variables, ads description; deals description; messages/notifications.

\section{Proposed Business Model}

For materializing the solution services depicted in Chart 4, the proposed system will involve three parties (see Figure 1):

(a) Mobile Marketing Provider: This is the business organization owning and managing the mobile marketing system that provides all of the services for merchants (WSr- $i$ ) and shoppers/customers (MSr-i). 
International Journal of Managing Information Technology (IJMIT) Vol.4, No.4, November 2012

(b) Merchants: In order to be the members, merchants must sign up on to the provider website. There are four kinds of memberships offered (see descriptions of the Revenue model below). Merchants can access the provided services (WSr-i) from anywhere at any time using their computers connected to the Internet.

(c) Shoppers/customers: To encourage internet users to be the system member, the membership for shoppers is free. Shoppers must download the mobile application from the provider website, installed in their mobile device, and sign up as members. Then, they can access the mobile services (MSr-i) using their mobile devices.

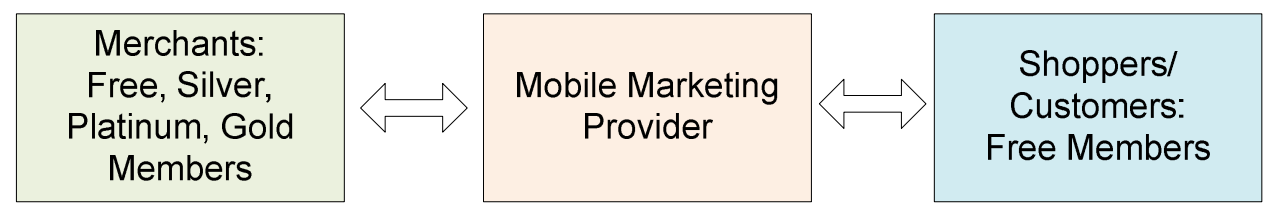

Figure 1. Three parties involved in the system: Mobile Marketing Provider, Merchants and Shoppers

It is presented in Sub-section 2.2 that any business model must address eight key elements. In this research (conducting the requirement and analysis stage of CBIS development), six of them are addressed as follows:

(a) Value proposition: In general, by providing mobile services (MSr-1 to MSr-16) and website services (WSr-1 to WSr-4) that are accepted by users, it is expected that the propose system will be valuable by mobile users and merchants. Mobile users will get valuable information while merchants will be able to market their products effectively.

(b) Revenue model: The revenue comes from merchant membership fees. There are four kinds of memberships, namely free, silver, gold and platinum, where each kind will be applied with different annual fee. The following is the features for each type of member: (1) Free: Display 10 product catalogs, create 10 ads/month, 10 deals/month; (2) Silver: Display 100 product catalogs, create 100 ads/month, 100 deals/month; (3) Gold: Display unlimited catalogs, create $100 \mathrm{ads} / \mathrm{month}$, unlimited deals/month; (4) Platinum: Display and create unlimited catalogs, ads and deals. Members may upgrade or downgrade their memberships accordingly. Once the website has high hits, the website can then launch paid ads service as the additional revenue.

(c) Market opportunity: Millions of mobile users use their devices to access the Internet (see Section 1). Therefore, there are business opportunities to provide mobile services by utilizing the connection Internet that will benefit these users. There are also millions of micro-smallmedium enterprises in Indonesia [24], where some parts of them are merchants that need to market their products. The opportunities that will be caught are advertising services directed towards mobile device users such that the member merchants able to market their products effectively.

(d) Competitive environment and advantage: To our knowledge, currently there is no company in Indonesia offering the services for mobile devices users and merchants that we design. Therefore, we assume that the new services will attract them.

(e) Organizational development: At the early stage, the mobile marketing provider company will need to develop two divisions having the task: (1) To manage general data which are changed infrequently, such as merchants, shoppers/customers, product categories and market segmentations; (2) To manage operational data which are changed/added frequently, such as 
product catalogs, ads, deals/coupons and reports from merchants/ shoppers/ users. Later on, when the two divisions cannot handle their tasks due to heavy transactions or data update, the division can further be divided with each division handles more specific tasks. On the other hand, merchants using the services will need to assign at least one person responsible to update catalog, post ads and deals.

\section{Proposed Mobile Marketing System Model}

It is known that the components of CBIS are people, computer and network infrastructures, procedures, software and database. The proposed mobile marketing system is an integrated CBIS therefore the system model will be presented with the model of each component. In this model, the customers will be regarded as shoppers.

\subsection{Network Infrastructure}

To implement the proposed business model, the information technology infrastructure needed is as shown in Figure 2 with the following description:

(a) The provider must own (or rent) a server or cluster of servers connected to the Internet that will run and manage a website and database system.

(b) Merchants will access services WSr-1 to WSr-4 via their computer connected to the Internet.

(c) Shoppers will use their mobile devices for accessing services MSr-1 to MSr-16.

(d) In order to send location-aware-information to shoppers' mobile devices, the provider website will employ cloud services provided by Cloud Services Providers, such that shoppers will receive information posted or updated by nearby merchants only.

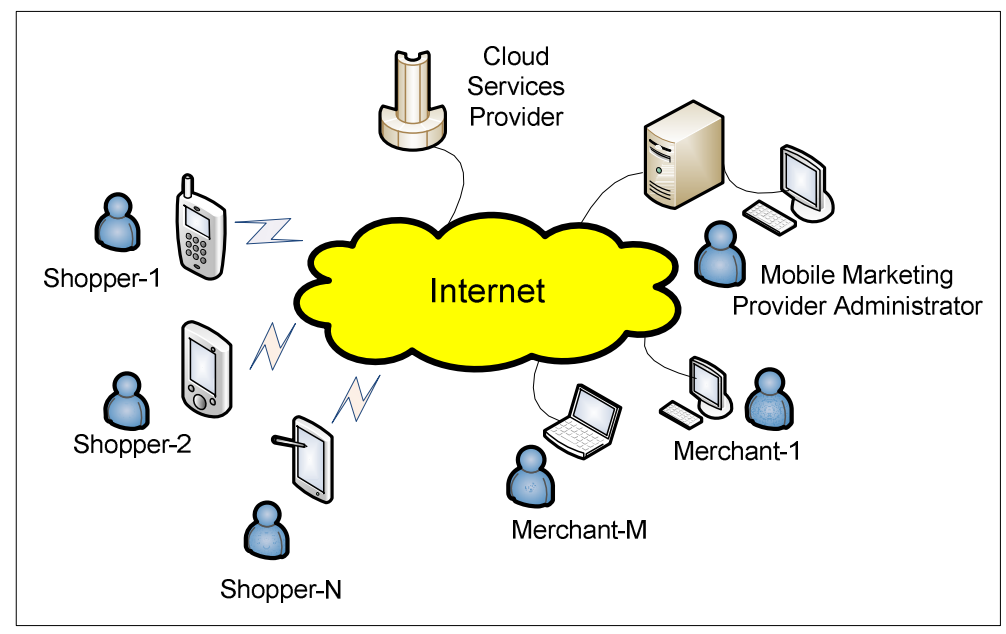

Figure 2. The network topology of the proposed system 
International Journal of Managing Information Technology (IJMIT) Vol.4, No.4, November 2012

\subsection{People and System Procedures}

The people or users involved in the systems are provider administrator, merchants and shoppers. In using the proposed system, we design nine main procedures. The excerpts are as follows:

P-1. Merchant registration and membership upgrade: Merchants may sign up on to the provider website, the website will verify and then merchants become free members. In the future, merchants may upgrade their memberships to silver, premium or gold by paying certain annual fee.

P-2. Shopper registration: First, shoppers must download the mobile marketing application from the provider website and install it into their mobile devices. By using the application, shoppers then register to the system. After the registrations are verified by the provider administrator, shoppers become free members and can use the system services.

P-3. Managing product categories: Before merchants can manage their product catalogs, the provider administrator must input product categories into the website database. Then, from time to time, these categories can be updated accordingly and shoppers will be notified of this update in real time basis by using cloud services such that the product categories stored in the local mobile database can be adjusted.

P-4. Managing market segmentation variables: Before merchants can manage their ads/deals with the corresponding market segment, the administrator must configure or provide the variables stored in the website database that will be used to determine merchants market segmentations.

P-5. Managing product catalogs: After product categories are available, merchants can add/update/delete their catalogs. The changes will be verified by administrator and the system will promptly send notification of the changes to nearby shoppers by using cloud services.

P-6. Managing ads: After market segmentation variables and product catalogs are available, merchants can add/update/delete ads associated to certain products by providing values to market segmentation variables (the variables are then used by website functions to compute the ads market segment). After the ads are verified by the provider administrator, notifications will be broadcasted to nearby targeted shoppers (indicated by the market segment) using cloud services.

P-7. Managing deals: The procedure is similar to P-6.

P-8. Managing shoppers' profiles, peers and selected/preferred product categories: Shoppers may from time to time update their profiles, peers and selected product categories stored in their own local database in the mobile device.

P-9. Taking and claiming deals: Upon receiving the deals matching their profile, shopper may "take" (book) certain deals and this information will be sent to the provider website and stored in its database. Shoppers then can go to the merchant stores and claim/redeem the deals along with purchasing the desired products. The clerk in the store will make sure that the shopper marks that the deals as claimed in their mobile device application (this claimed status will be sent to the provider website and stored in the website database). 


\subsection{Software}

For materializing the designed services (see Chart 4) and procedures (see Section 6.2), the CBIS of mobile marketing system is divided into two sub-systems (see Figure 3), which are a website installed and run in the provider server, and a client mobile application run in every shopper's mobile device (see the network topology shown in Figure 2 ).

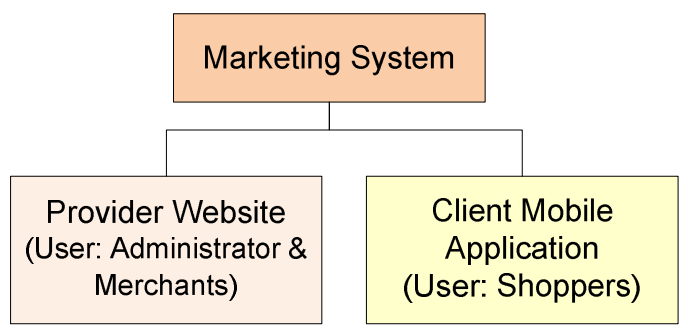

Figure 3. The proposed mobile marketing consists of provider website and client mobile application

The provider website is further divided into two modules, namely Phost A and Phost $M$ (see Figure 4), where each module consists of several sub-modules that are used by certain users, where each sub-module has functions materializing the services designed (see Chart 5).

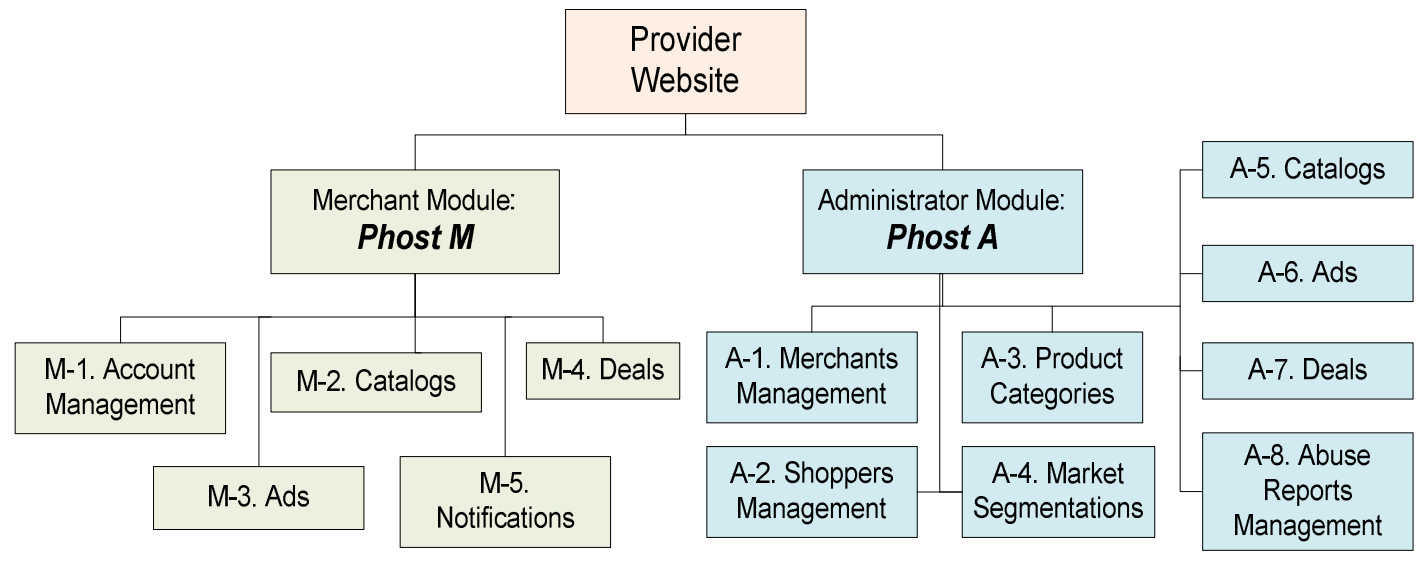

Figure 4. The architecture of the website owned and run by the provider

Chart 5. List of functions, users and services materialized in Phost- $M$ and Phost-A sub-modules

\begin{tabular}{|l|l|l|l|}
\hline Sub-module & User & \multicolumn{1}{|c|}{ Website Functions } & \multicolumn{1}{c|}{$\begin{array}{c}\text { Services } \\
\text { Materialized }\end{array}$} \\
\hline $\begin{array}{l}\text { M-1. } \\
\text { Account } \\
\text { Management }\end{array}$ & Merchant & $\begin{array}{l}\text { Register, sign in, manage the merchant's } \\
\text { profile and upgrade membership. }\end{array}$ & $\begin{array}{l}\text { - (additional } \\
\text { necessary } \\
\text { function) }\end{array}$ \\
\hline $\begin{array}{l}\text { M-2. } \\
\text { Catalogs }\end{array}$ & Merchant & $\begin{array}{l}\text { View, insert, update, delete product catalogs, } \\
\text { view and reply users' comments and show } \\
\text { merchant location. }\end{array}$ & WSr-1 \\
\hline M-3. Ads & Merchant & $\begin{array}{l}\text { View, insert, update and delete product } \\
\text { advertisings including their market } \\
\text { segments, minimum confidence and period } \\
\text { of the advertisings. }\end{array}$ & $\begin{array}{l}\text { WSr-2; } \\
\text { WSr-3 }\end{array}$ \\
\hline
\end{tabular}


International Journal of Managing Information Technology (IJMIT) Vol.4, No.4, November 2012

\begin{tabular}{|c|c|c|c|}
\hline Sub-module & User & Website Functions & $\begin{array}{c}\text { Services } \\
\text { Materialized }\end{array}$ \\
\hline M-4. Deals & Merchant & $\begin{array}{l}\text { View, insert, update and delete product deals } \\
\text { offered to shoppers/customers including } \\
\text { their market segments, minimum confidence } \\
\text { and period of the advertisings; } \\
\text { Process deals taken by shoppers; }\end{array}$ & $\begin{array}{l}\text { WSr-2; } \\
\text { WSr-3 }\end{array}$ \\
\hline $\begin{array}{l}\text { M-5. } \\
\text { Notifications }\end{array}$ & Merchant & View and reply notifications received. & $\begin{array}{l}\text { - (additional } \\
\text { necessary } \\
\text { function) }\end{array}$ \\
\hline $\begin{array}{l}\text { A-1. } \\
\text { Merchants } \\
\text { Management }\end{array}$ & Administrator & $\begin{array}{l}\text { View, verify (new) merchants, verify } \\
\text { membership upgrade. }\end{array}$ & WSr-4 \\
\hline $\begin{array}{l}\text { A-2. } \\
\text { Shoppers } \\
\text { Management }\end{array}$ & Administrator & View and verify (new) shoppers. & $\begin{array}{l}\text { - (additional } \\
\text { necessary } \\
\text { function) }\end{array}$ \\
\hline $\begin{array}{l}\text { A-3. Product } \\
\text { Categories }\end{array}$ & Administrator & $\begin{array}{l}\text { View, insert, update and delete product } \\
\text { categories. Examples of categories: fashion, } \\
\text { book, food and drinks, etc. }\end{array}$ & WSr-1 \\
\hline $\begin{array}{l}\text { A-4. Market } \\
\text { Segmentation } \\
\text { s }\end{array}$ & Administrator & $\begin{array}{l}\text { View, insert, update and delete market } \\
\text { segmentations (market variables and values). } \\
\text { Examples of variables: age (values: }<20,21- \\
30,31-40 \text { ), gender (values: male and } \\
\text { female). }\end{array}$ & WSr-2 \\
\hline $\begin{array}{l}\text { A-5. } \\
\text { Catalogs }\end{array}$ & Administrator & $\begin{array}{l}\text { View and verify product catalogs posted by } \\
\text { merchants. }\end{array}$ & WSr-1 \\
\hline A-6. Ads & Administrator & $\begin{array}{l}\text { View and verify product advertisings posted } \\
\text { by merchants. After the ads are verified by } \\
\text { Administrator, notifications are promptly } \\
\text { broadcasted to shoppers' mobile devices via } \\
\text { a cloud service. }\end{array}$ & $\begin{array}{l}\text { WSr-2; } \\
\text { WSr-3 }\end{array}$ \\
\hline A-7. Deals & Administrator & $\begin{array}{l}\text { View and verify product deals posted by } \\
\text { merchants. After the deals are verified by } \\
\text { Administrator, notifications are promptly } \\
\text { broadcasted to shoppers' mobile devices via } \\
\text { a cloud service. }\end{array}$ & $\begin{array}{l}\text { WSr-2; } \\
\text { WSr-3 }\end{array}$ \\
\hline $\begin{array}{l}\text { A-8. Abuse } \\
\text { Reports } \\
\text { Management }\end{array}$ & Administrator & $\begin{array}{l}\text { View and update the status of the system } \\
\text { abuse reports. }\end{array}$ & $\begin{array}{l}\text { - (additional } \\
\text { necessary } \\
\text { function) }\end{array}$ \\
\hline
\end{tabular}

Note: Sr-2 (simple user interfaces for shoppers) is not resolved by Phost-A and Phost-M but Phost C.

The mobile application, namely Phost $C$, is broken down into several modules (see Figure 5), where each module has functions and materializes certain designed services (see Chart 6). 
International Journal of Managing Information Technology (IJMIT) Vol.4, No.4, November 2012

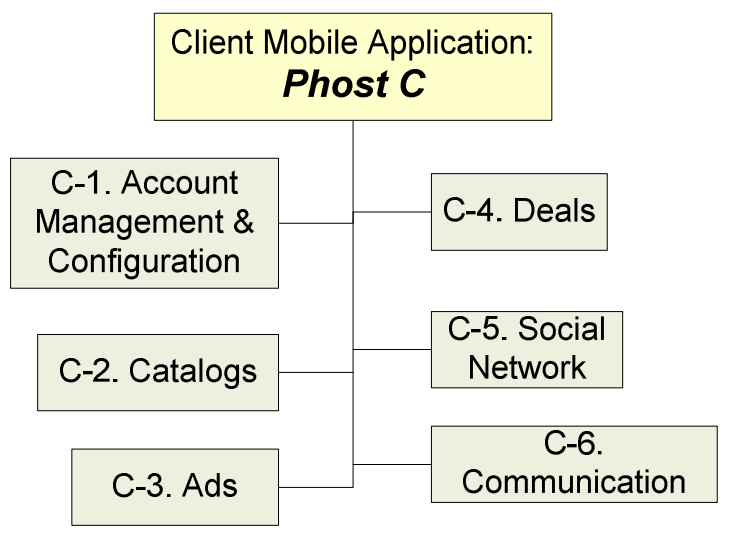

Figure 5. The architecture of the client mobile application

Chart 6. List of functions and services materialized in Phost-C modules

\begin{tabular}{|c|c|c|}
\hline Module & Functions & $\begin{array}{c}\text { Services } \\
\text { Materialized }\end{array}$ \\
\hline $\begin{array}{l}\text { C-1. Account } \\
\text { Management \& } \\
\text { Configuration }\end{array}$ & $\begin{array}{l}\text { Manage profile content (used for } \\
\text { filtering/personalizing ads and deals received); Set } \\
\text { preferred product categories filter settings (used for } \\
\text { filtering/personalizing product catalogs). }\end{array}$ & $\begin{array}{l}\text { MSr-1; MSr-3; } \\
\text { MSr-15 }\end{array}$ \\
\hline C-2. Catalogs & $\begin{array}{l}\text { Manage/select the desired product categories; Search } \\
\text { and view information of specific products, related } \\
\text { deals, comments; Compare products; Show the } \\
\text { location of a merchant; Mark/unmark the products (as } \\
\text { product favorite); View related advertising/deals of a } \\
\text { product. }\end{array}$ & $\begin{array}{l}\text { MSr-3; MSr-5; } \\
\text { MSr-6; MSr-9; } \\
\text { MSr-11; MSr- } \\
12 ; \text { MSr-16 }\end{array}$ \\
\hline C-3. Ads & $\begin{array}{l}\text { View advertising contents and the related product } \\
\text { information; Delete advertisings; Share advertisings to } \\
\text { peers. }\end{array}$ & $\begin{array}{l}\text { MSr-4; MSr-6; } \\
\text { MSr-7; MSr- } \\
10\end{array}$ \\
\hline C-4. Deals & $\begin{array}{l}\text { View deals sent by merchants (that are filtered by } \\
\text { shopper profiles stored in the local database of } \\
\text { shopper's mobile device); Take a deal (submit } \\
\text { information that the deal is accepted/reserved by the } \\
\text { shopper to the merchant offering the deal); Claim deals } \\
\text { (submit information that the product has been } \\
\text { purchased in the merchant store); Delete deals; Share } \\
\text { deals to peers. }\end{array}$ & $\begin{array}{l}\text { MSr-4; MSr-5; } \\
\text { MSr-6; MSr-7; } \\
\text { MSr-10; MSr- } \\
16\end{array}$ \\
\hline $\begin{array}{l}\text { C-5. Social } \\
\text { Network }\end{array}$ & $\begin{array}{l}\text { Add other shoppers as friends; Read } \\
\text { notifications/messages from peers; Share product } \\
\text { information to peers; Ask peers opinions of certain } \\
\text { products; Share advertisings to peers. }\end{array}$ & $\begin{array}{l}\text { MSr-13; } \\
\text { MSr-14 }\end{array}$ \\
\hline $\begin{array}{l}\text { C-6. } \\
\text { Communication }\end{array}$ & $\begin{array}{l}\text { Handle and process push messages (sent by the } \\
\text { provider server through the selected cloud service } \\
\text { provider). }\end{array}$ & $\begin{array}{l}\text { MSr-7; MSr-8; } \\
\text { MSr-9 }\end{array}$ \\
\hline
\end{tabular}

Note: MSr-2 (simple, self-explanatory, easy and consistent navigation user interfaces) will be materialized in the design stage. 
International Journal of Managing Information Technology (IJMIT) Vol.4, No.4, November 2012

\subsection{Database Model}

The stages in designing the database for CBIS consists of three major stages, which are conceptual, logical and physical database design [4]. The conceptual design can be included in the system analysis of CBIS development, while the two others can be conducted along with the system design. Conceptual database design aims to construct a model of the information used in an organization, independent of all physical considerations. Entity-relationship (E-R) diagram can be used to model the structure of the database storing the information graphically [16].

To resolve a few of mobile marketing criteria, we propose two separate databases: One is the database stored in the provider server that is accessed by Phost $A$ and Phost $M$ and the other is local database resided in the mobile devices accessed by Phost $C$ (see Figure 6). The database in the server stores a variety of large data needed by the mobile marketing system while the local database stores private data belonging to the shoppers.

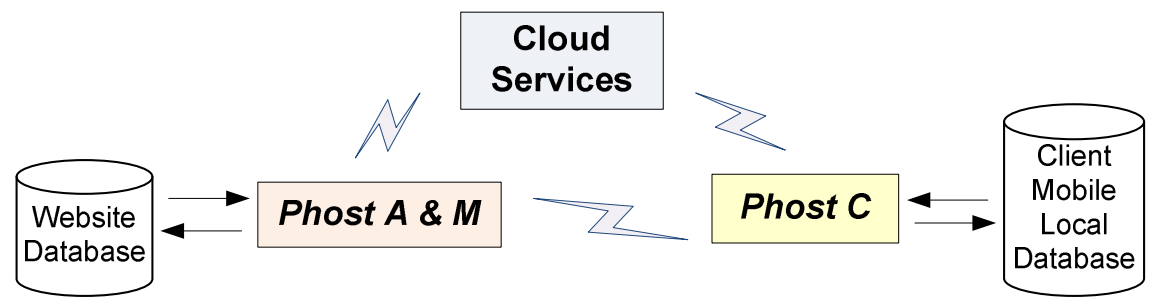

Figure 6. Phost $A \& M$ accesses database in the server while Phost $C$ accesses local database in the mobile device

Website Database This database model is represented with a simple entity-relationship diagram as shown in Figure 7. It can be seen that the database will store a variety of data, such as merchants, product categories, products, ads, deals, market segmentation, and so on. Each entity will have necessary attributes (see Chart 7).

Chart 7. The identified entities and main attributes of the website database

\begin{tabular}{|l|l|l|}
\hline No & \multicolumn{1}{|c|}{ Entity } & \multicolumn{1}{c|}{ Attributes } \\
\hline 1 & Category & IdCat, name, image \\
\hline 2 & Product & $\underline{\underline{\text { IdProd}}, \text { name, price, image }}$ \\
\hline 3 & Merchant & $\begin{array}{l}\text { IdMerchant, name, email, address, city, map_location, } \\
\text { member_type, isActive }\end{array}$ \\
\hline 4 & Shopper & $\underline{\text { DeviceId, email, isBlocked }}$ \\
\hline 5 & Ad & $\underline{\text { IdAd, title, content, datetime, status }}$ \\
\hline 6 & Deal & IdDeal, title, content, datetime, status, expired_time, stock \\
\hline 7 & MarketSegment & IdSeg, name \\
\hline 8 & MerchantNotification & $\underline{\text { IdNot, message, datetime }}$ \\
\hline 9 & ShopperNotification & $\underline{\text { IdNotShop, from, title, message, senttime, isRead }}$ \\
\hline 10 & ReportAbuse & $\underline{\text { IdRep, }, \text { comment }}$ \\
\hline
\end{tabular}




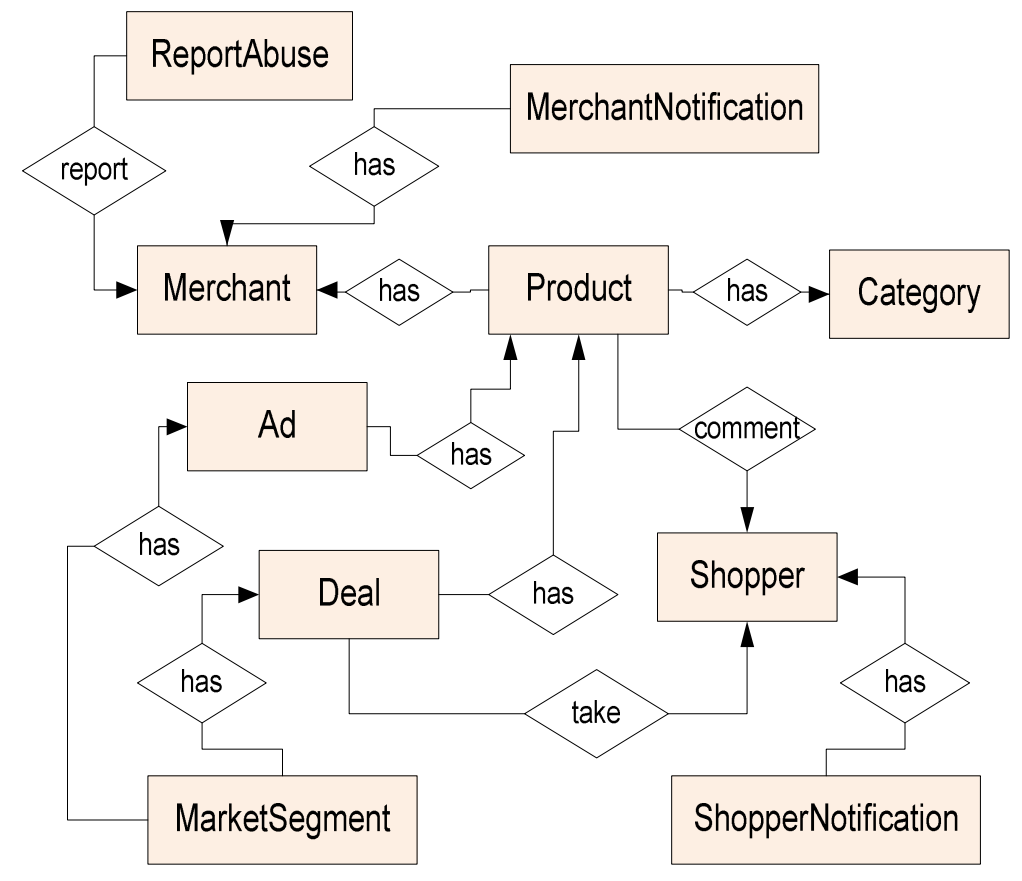

Figure 7. The E-R diagram of the website database

Mobile Local Database The objective of making Phost $C$ accessing local mobile database (not the server database via the Internet) is to resolve a few of the mobile marketing criteria as shown in Chart 8. The local database model itself is represented with the simple E-R diagram depicted in Figure 8 with the main attributes of each entity are presented in Chart 9.

Chart 8. The acceptance criteria resolved by designing mobile local database

\begin{tabular}{|c|l|l|}
\hline No & Concept/Criteria & \multicolumn{1}{c|}{ Rationales } \\
\hline $\begin{array}{l}\text { Cr-4, } \\
\text { Cr-5 }\end{array}$ & $\begin{array}{l}\text { personalization, } \\
\text { compelling } \\
\text { content }\end{array}$ & $\begin{array}{l}\text { The local database stores shoppers' profiles and other data that can } \\
\text { be used by the mobile application functions to personalize ads and } \\
\text { deals such that shoppers only receive the desired/relevant } \\
\text { information. It also stores the preferred product categories such } \\
\text { that the application functions can display only the products in the } \\
\text { selected categories. }\end{array}$ \\
\hline Cr-12 & $\begin{array}{l}\text { social network } \\
\text { services }\end{array}$ & $\begin{array}{l}\text { The local database stores shopper peers data (such as email } \\
\text { addresses) such that the social network application functions } \\
\text { access the data needed locally; } \\
\text { The database also stores messages/notifications from peers. }\end{array}$ \\
\hline Cr-13 & $\begin{array}{l}\text { privacy } \\
\text { protection }\end{array}$ & $\begin{array}{l}\text { Shoppers profiles (used to filter/personalize the advertisings and } \\
\text { deals received in the mobile devices), messages/notifications, } \\
\text { selected product categories and products information and selected } \\
\text { deals are stored in shoppers' mobile database and are not } \\
\text { accessed/ known by merchants as well as other shoppers. }\end{array}$ \\
\hline
\end{tabular}

Note: For design consideration, creating a local database for the mobile application also has other advantages (such as increasing database access speed). 
International Journal of Managing Information Technology (IJMIT) Vol.4, No.4, November 2012

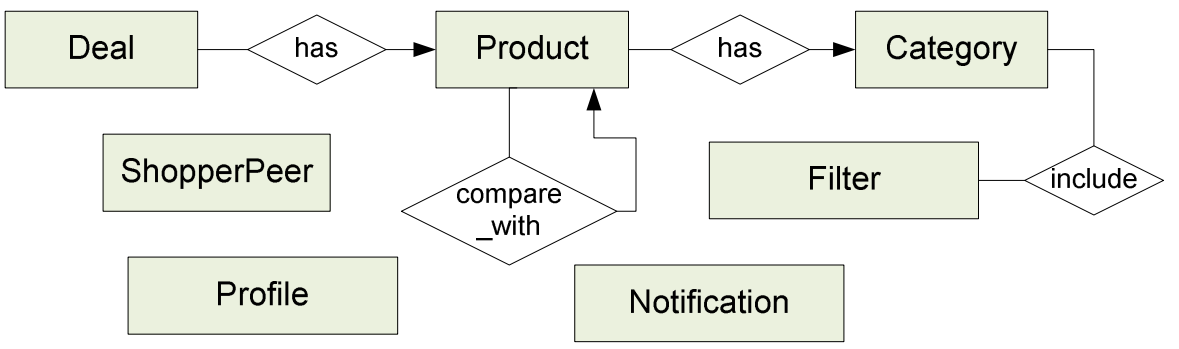

Figure 8. The E-R diagram of the mobile local database

Chart 9. The identified entities and main attributes of the local mobile database

\begin{tabular}{|l|l|l|}
\hline No & \multicolumn{1}{|c|}{ Entity } & \multicolumn{1}{c|}{ Attributes } \\
\hline 1 & Category & $\underline{\text { IdCat, name, image }}$ \\
\hline 2 & Product & $\underline{\text { IdProd, name, price, image }}$ \\
\hline 3 & Deal & $\underline{\text { IdDeal, title, content, expired_time, status }}$ \\
\hline 4 & ShopperPeer & DeviceId, email \\
\hline 5 & Profile & $\underline{\text { IdProfile, name, value }}$ \\
\hline 6 & Notification & $\underline{\text { IdNot, from, title, sent, message, isRead }}$ \\
\hline 7 & Filter & $\underline{\text { IdCat, isSelected }}$ \\
\hline
\end{tabular}

\section{Model Evaluation}

One of activity that must be conducted in a CBIS development is reviewing the result of each stage. In this section, we present the brief excerpt of the system model review.

The system model (network infrastructure, procedures, software and database) have fully support the business objective defined, which is to provide services for merchants to market their products to customers who own mobile devices with functionalities to access the Internet.

In order to provide mobile services that will be accepted by users, mobile services acceptance criteria have been searched by studying literature and the criteria found $(\mathrm{Cr}-1$ to $\mathrm{Cr}-13)$ have been resolved into website services (WSr-1 to $\mathrm{WSr}-4$ ) as well as mobile services (MSr-1 to $\mathrm{WSr}-16$ ). The system procedures have been designed such that the use of the services is arranged properly. The website services designed are then translated into the website sub-systems (Phost-A and Phost-M) module functions, while the mobile services into mobile Phost-C module functions. The database model facilitating the information needed and managed by Phost-A, Phost- $M$ and Phost- $C$ has also been constructed. In addition, some mobile services acceptance criteria are also resolved by local mobile database model.

However, there is one criterion that has not been fully resolved, which is $\mathrm{Cr}-5$ (compelling content). This should be translated into services providing entertainment, amusement and enjoyment. In the context of product advertising, these may be materialized by providing cartoons, funny or interesting video clip, and so on. In our design, compelling content currently is mainly translated into providing deals only.

\section{CONCLuSion}

The computer-based information system (CBIS) model used in e-commerce mobile marketing that resolves user acceptance criteria (ease of use, personalization, up-to-date content, incentive, social network, and so on) needs to be materialized into an integrated system consisting two sub- 
International Journal of Managing Information Technology (IJMIT) Vol.4, No.4, November 2012

systems, which are a website used by the service provider and merchants, and a mobile application used by mobile device users.

In order to develop a system meeting the user acceptance criteria, a combination of CBIS, ecommerce website and mobile application development methods should be adopted, where the requirement stage is improved to facilitate e-commerce website and mobile application development. (As suggested in [8], in developing e-commerce system consumers' behavior must be studied and resolved carefully. This research has contributed in resolving some part of ecommerce system, specifically the mobile marketing sub-system.)

As in this research we conduct activities of requirement and analysis only, further work is required, which includes activities of system design, implementation and testing. Organizations with e-commerce businesses may adopt and work further with the proposed model as an independent system or as part of their systems to support product marketing activities. In either case, model customizations may be needed such that the business model and procedures are suitable with the organizations conditions, then the enterprises organizational structure may need to be enhanced to manage the system, and collaboration with cloud services provider should be set up. For research purpose, a prototype may be built based on the model, which then can be deployed, and the mobile users' acceptances of the system are evaluated. Currently, a prototype is being developed and the working designed is depicted in [5].

\section{REFERENCES}

[1] Ashraf, M. F., Kamal, Y. (2010), “Acceptance of mobile marketing among university students", Mustang Journal of Business \& Ethics.

[2] Avison, D. and Fitzgerald, G. (2006), Information Systems Development, Methodologies, Techniques and Tools 4th ed., McGraw Hill, USA.

[3] Broeckelmann, P. (2010), "Exploring consumers' reactions towards innovative mobile services", Qualitative Market Research: an International Journal, Vol. 13 No. 4, pp. 414-429.

[4] Connolly, T. and Begg, C. (2002), Database Systems A Practical Approach to Design, Implementation and Management, 3rd ed., Addison Wesley Pub., USA.

[5] Criswanto, D.N. (2012), Development of Android-Based Commerce Mobile System Providing Mobile Marketing Services, Draft of Final Project, Informatics Department, Parahyangan Catholic University, Indonesia.

[6] Fling, B., (2009), Mobile Design and Development, O'Reilly Media, Inc., USA.

[7] Gao, T., Sultan, F. and Rohm, A. J. (2010), "Factors influencing Chinese youth consumers' acceptance of mobile marketing". Journal of Consumer Marketing, Vol. 27 No. 7, pp. 574-583.

[8] Johar, G. and Awalluddin, J. A. A. (2011), “The Role of Technology Acceptance Model in Explaining Effect on e-Commerce Application System", International Journal of Managing Information Technology (IJMIT), Vol.3, No.3, pp. 1-14.

[9] Laudon, K.C. and Traver, C.G. (2011), E-commerce 2011 Business Technology Society 7th ed. Pearson Education, Inc., England.

[10] Liu, Y. and Li, H. (2009), "Mobile internet diffusion in China: an empirical study", Industrial Management \& Data Systems, Vol. 110 No. 3, pp. 309-324. 
International Journal of Managing Information Technology (IJMIT) Vol.4, No.4, November 2012

[11] Liu, Z., Bonazzi, R., Fritscher, B. and Pigneur, Y. (2011), "Privacy-friendly business models for location-based mobile services", Journal of Theoretical and Applied Electronic Commerce Research, Vol. 6 Issue 2, pp. 90-107

[12] Mather, T., Kumaraswamy, S. and Latif, S., (2009), Cloud Security and Privacy, O'Reilly Media, Inc., USA.

[13] Palka, W., Pousttchi, K. and Wiedemann, D.G. (2009), "Mobile word-of-mouth - a grounded theory of mobile viral marketing", Journal of Information Technology, Vol. 24, pp. 172-185.

[14] Rao, S. and Troshani, I. (2007), “A Conceptual framework and propositions for the acceptance of mobile services", Journal of Theoretical and Applied Electronic Commerce Research, Vol. 2 Issue 2, pp. $61-73$.

[15] Reese, G. (2009), Cloud Application Architectures, O'Reilly Media, Inc., USA.

[16] Silberschatz, A., Korth, H. F. and Sudarshan, S. (2006), Database System Concepts 5th ed., McGraw Hill, USA.

[17] Unhelkar, B and Murugesan, S. (2010), "The enterprise mobile applications development framework", Mobile Computing, IEEE Computer Society, USA.

[18] Yang, K. (2010), "Determinants of US consumer mobile shopping services adoption: implications for designing mobile shopping services”, Journal of Consumer Marketing, Vol. 27 No. 3, pp. 262-270.

[19] Younes, A. and Megdadi, A. (2011), "Shopping consumer attitudes toward mobile marketing: a case study among Jordanian user's”, International Journal of Marketing Studies, Vol. 3, No. 2, pp. 53-63.

[20] Zarmpou, T., Saprikis, V., Markos, A. and Vlachopoulou, M. (2012), "Modeling users' acceptance of mobile services", Electronic Commerce Research, Vol. 12, pp. 225-248.

[21] Asia Internet Use (2011), "Population data and Facebook statistics", available at http://internetworldstats.com (accessed 6 August 2012)

[22] Google Developers (2012), "Android cloud to device messaging framework" available at https://developers.google.com/android/c2dm/ (accessed 26 June 2012).

[23] Martinus, A. (2012), "SparxUp: let's go mobile !!!", available at http://www.indonesiakreatif.net (accessed 6 August 2012).

[24] Musnandar, A. (2012), "Peran UKM dalam pertumbuhan ekonomi bangsa", available at http://www.uin-malang.ac.id (accessed 10 August 2012).

[25] VivaNews (2012), “Indonesia pengakses mobile internet terbesar", available at http://bisnis.news.viva.co.id (accessed 6 August 2012). 